\title{
Non-contiguous finished genome sequence and description of Oceanobacillus massiliensis sp. nov.
}

\author{
Véronique Roux ${ }^{1{ }^{*}}$, Matthieu Million ${ }^{1}$, Catherine Robert ${ }^{1}$, Alix Magne ${ }^{1}$ and Didier Raoult ${ }^{1}$ \\ ${ }^{1}$ Aix Marseille Université, URMITE, Faculté de médecine, Aix-Marseille Université, \\ Marseille, France \\ *Correspondence: Véronique Roux (veronique.roux@univ-amu.fr)
}

Keywords: Oceanobacillus massiliensis, Firmicutes, Polar flagellum

Oceanobacillus massiliensis strain N'Diop sp. nov. is the type strain of O. massiliensis sp. nov., a new species within the genus Oceanobacillus. This strain, whose genome is described here, was isolated from the fecal flora of a healthy patient. O. massiliensis is an aerobic rod. Here we describe the features of this organism, together with the complete genome sequence and annotation. The 3,532,675 bp long genome contains 3,519 protein-coding genes and 72 RNA genes, including between 6 and 8 rRNA operons.

\section{Introduction}

Oceanobacillus massiliensis strain N'diop ${ }^{\mathrm{T}}$ (CSUR $132^{\mathrm{T}}=$ DSM $24644 \mathrm{~T}$ ) is the type strain of 0. massiliensis sp. nov. This bacterium is a Grampositive strictly aerobic rod, motile by a polar flagellum and was isolated from the stool of a healthy Senegalese patient as part of a "culturomics" study aiming at cultivating individually all species within human feces [1].

Presently, "the gold standard method" to define a bacterial species is DNA-DNA hybridization [2]. But this method is time-consuming and the interlaboratory reproducibility is poor. So, with the development of PCR and sequencing methods, $16 \mathrm{~S}$ rRNA gene sequence comparison with internationally-validated cutoff values constitutes, for most bacterial genera, a reliable, reproducible and comparable tool that enables the taxonomic classification of new bacterial species [3]. Recently, it was proposed that new bacterial taxa be described using a polyphasic approach [4] that would include the genome sequence, MALDI-TOF spectrum and main phenotypic characteristics (habitat, Gramstain reaction, culture, cell wall structure and metabolic characteristics).

Here we present a summary classification and a set of features for 0 . massiliensis sp. nov. strain Ndiop ${ }^{\mathrm{T}}$ together with the description of the complete genomic sequencing and annotation. These characteristics support the circumscription of the species $O$. massiliensis.

The genus Oceanobacillus was first described by Lu et al. [5] and was emended by Yumoto et al. [6]. The genus comprises 12 recognized species and two subspecies. These bacteria are motile Gram- positive rods, obligately aerobic or facultatively anaerobic, obligately or facultatively alkaliphilic. These species were isolated from deep-sea sediment core [5,7], deteriorated mural paintings [8], salt field [9], freshwater fish [10], algal mat [11], insects in freshwater [12], Bacillus-dominated wastewater treatment system in Korea [13], fermented shrimp paste samples [14], soy sauce production equipment [15], a marine solar saltern [16], activated sludge in a bioreactor [17], traditional Korean fermented food [18] and a fermented Polygonum indigo liquor sample [19]. These bacteria belong to the phylum Firmicutes, in the family Bacillaceae. There is no evidence of pathogenicity of these bacteria.

\section{Classification and features}

A stool sample was collected from a healthy 16year-old male Senegalese volunteer patient living in N'diop (a rural village in the Guinean-Sudanian zone in Senegal), who was included in a research protocol. The patient gave an informed and signed consent, and the agreements of the National Ethics Committee of Senegal and the local ethics committee of the IFR48 (Marseille, France) were obtained under agreement 09-022 and 11-017. The fecal specimen was preserved at $-80^{\circ} \mathrm{C}$ after collection and sent to Marseille. Strain N'diop (Table 1) was isolated in January 2011 by aerobic cultivation on $5 \%$ sheep blood-enriched Columbia agar (BioMerieux).

The bacterial DNA was extracted using the MagNA Pure LC DNA isolation kit III (Roche, Mannheim, Germany) with the MagNA Pure LC instrument as described by the manufacturer. 
PCR amplification of the 16S rRNA gene was performed using the universal primer pair fD1 and rp2 [35]. PCR products were purified using MultiScreen PCR (Millipore) and sequencing reactions were carried out using a DNA sequencing kit (BigDye Terminator Cycle Sequencing v1.1 Ready Reactions, PE biosystems) according to the manufacturer's instructions. Sequencing products were purified and electrophoresis was performed with the 3130 Genetic Analyzer (Applied Biosystems). Base insertions were noted at the beginning and the end of the gene sequence. So, we tried to clone PCR products in pGEM-T Easy Vector (Promega) as described by the manufacturer. But the sequence was too long and no result was obtained. A new primer Omassr (GCCTGCAATCCGAACTGAGA) was chosen to reduce the length of fragment when combined with fD1 to perform PCR amplification. Seventeen clones were PCR amplified using the primers M13d (CGCCAGGGTTTTCCCAGTCACGAC) and M13r (TCACACAGGAAACAGCTATGAC) and the obtained products were sequenced. The obtained sequences were compared with sequences deposited in the GenBank database by using the BLAST program through the NCBI server. This strain exhibited a 96.4-97\% nucleotide sequence similarity with 0 . profundus, the phylogenetically closest validated Oceanobacillus species. Gene sequences were aligned using the multisequence alignment program CLUSTAL X (1.8) [36]. Phylogenetic relationships with closely related species were determined by using MEGA version 5.0 [37]. Distance matrices were determined following the assumptions described by Kimura and were used to elaborate a dendrogram using the neighbor-joining method (Figure 1). The maximum-parsimony algorithm was also used to infer phylogenetic analysis. A bootstrap analysis (bootstrap values were obtained for a consensus tree based on 1,000 randomly generated trees) was performed to investigate the stability of the trees obtained. The clustering of the new isolate was the same with the two methods.

For DNA-DNA hybridization, cells were disrupted by using a French pressure cell (Thermo Spectronic) and the DNA in the crude lysate was purified by chromatography on hydroxyapatite as described by Cashion et al. [38]. DNA-DNA hybridization was carried out as described by De Ley et al. [39] under consideration of the modifications described by Huss et al. [40] using a model Cary 100 Bio UV/VIS-spectrophotometer equipped with a Peltier-thermostatted $6 \times 6$ multicell changer and temperature controller with in-situ temperature probe (Varian). DNA-DNA reassociation rate was $25.5 \%$ between strain NdiopT and Oceanobacillus profundus. So, they did not belong to the same species when the recommendations of a threshold value of 70\% DNA-DNA similarity for the definition of bacterial species by the ad hoc committee are considered [41].

Surface colonies were observed on sheep blood agar (bioMérieux) after $24 \mathrm{~h}$ aerobic incubation at $37^{\circ} \mathrm{C}$. The colonies of the strain N'diopT were circular, greyish, shiny and smooth, 2-5 mm in diameter. Gram staining showed Gram-positive bacilli (Figure $2)$. Different growth temperatures $(25,30,37,45$ and $50^{\circ} \mathrm{C}$ ) were tested. Growth occurred between $25^{\circ} \mathrm{C}$ and $45^{\circ} \mathrm{C}$, and optimal growth was observed between $30^{\circ} \mathrm{C}$ and $37^{\circ} \mathrm{C}$. Growth of the strain was tested under aerobic atmosphere, in the presence of 5\% CO2, and also in anaerobic and microaerophilic atmospheres which were created using GENbag anaer and GENbag microaer (bioMérieux), respectively. The strain was aerobic and also grew in microaerophilia and in the presence of 5\% $\mathrm{CO} 2$ but did not grow in an anaerobic atmosphere. The $\mathrm{NaCl}$ concentrations allowing growth of strain N'DiopT, were determined on DifcoTMBrain Heart Infusion Agar plates (Becton Dickinson). The powder was supplemented with $\mathrm{NaCl}$ (Euromedex) to obtain the tested concentrations $(0.5,1,2,3,510,15 \%, \mathrm{w} / \mathrm{v})$. Growth occurred between $0.5-10 \% \mathrm{NaCl}$ but the optimum growth was between $0.5-5 \% \mathrm{NaCl}$. Growth in the range of pH 5.0-10.0 was tested using BBLTM Brain Heart Infusion (Becton Dickinson) supplemented with $5 \% \mathrm{NaCl}$. The final $\mathrm{pH}$ was adjusted with $\mathrm{HCl}$ or $\mathrm{NaOH}$ solution. Growth occurred between $\mathrm{pH}$ 7-9 but optimum $\mathrm{pH}$ was 7-8.

The size and ultrastructure of cells were determined by negative staining transmission electron microscopy. Cells were grown on Columbia agar with $5 \%$ sheep blood for $24 \mathrm{~h}$ at $37^{\circ} \mathrm{C}$. The bacteria were suspended in phosphate buffer (Gibco; $\mathrm{KCl}$ $200 \mathrm{mg} / \mathrm{L}, \mathrm{KH} 2 \mathrm{PO} 4200 \mathrm{mg} / \mathrm{L}, \mathrm{NaCl} 8 \mathrm{~g} / \mathrm{L}$, Na2HPO4-7H2O $2.16 \mathrm{~g} / \mathrm{L}$ ) and pre-fixed in 5\% $(\mathrm{v} / \mathrm{v})$ glutaraldehyde in phosphate buffer for at least $1 \mathrm{~h}$ at room temperature, washed in the same buffer and stained with $1 \%(\mathrm{w} / \mathrm{v})$ phosphotungstic acid. The samples were examined on a Morgagni 268D (Philips) electron microscope at an operating voltage of $60 \mathrm{kV}$. The rods were 1.2-1.9 $\mu \mathrm{m}$ long and 0.4-0.7 $\mu \mathrm{m}$ wide (Figure 3). Polar flagella were observed. 
Strain N'Diop ${ }^{\mathrm{T}}$ exhibited catalase activity and oxidase activity. The commercially available Api ZYM, Api 20NE (bioMérieux) were used to characterize the biochemical properties of the strain according to the manufacturer's instructions and incubation was performed at $37^{\circ} \mathrm{C}$ for $4 \mathrm{~h}$ and $24 \mathrm{~h}$, respectively. Api $50 \mathrm{CH}$ strips were inoculated with a heavy bacterial suspension in Api 50CHB/E medium supplemented with $5 \% \mathrm{NaCl}(\mathrm{w} / \mathrm{v})$ and incubation was performed at $37^{\circ} \mathrm{C}$ for $48 \mathrm{~h}$. Phenotypic characteristics were compared to those of species that were most closely related in terms of $16 \mathrm{~S}$ rRNA gene sequences. Characteristic traits are presented in Table 2.

Table 1. Classification and general features of Oceanobacillus massiliens is strain $\mathrm{N}^{\prime} \mathrm{Diop}^{\top}$ according to the MIGS recommendations [20]

\begin{tabular}{|c|c|c|c|}
\hline MIGS ID & Property & Term & ${\text { Evidence } \operatorname{code} \mathrm{e}^{\mathrm{a}}}$ \\
\hline & \multirow{8}{*}{ Current classification } & Domain Bacteria & TAS $[21]$ \\
\hline & & Phylum Firmicutes & TAS [22-24] \\
\hline & & Class Bacilli & TAS $[25,26]$ \\
\hline & & Order Bacillales & TAS $[27,28]$ \\
\hline & & Family Bacillaceae & TAS $[28,29]$ \\
\hline & & Genus Oceanobacillus & TAS $[5,30-33]$ \\
\hline & & Species Oceanobacillus massiliensis & IDA \\
\hline & & Type strain $\mathrm{N}^{\prime} \mathrm{Diop}^{\top}$ & IDA \\
\hline & Gram stain & Positive & IDA \\
\hline & Cell shape & Bacilli & IDA \\
\hline & Motility & Motile by polar flagellum & IDA \\
\hline & Sporulation & Nonsporulating & IDA \\
\hline & Temperature range & Mesophile & IDA \\
\hline & Optimum temperature & $37^{\circ} \mathrm{C}$ & IDA \\
\hline MIGS-6. 3 & Salinity & Growth in $\mathrm{BHI}$ medium $+5 \% \mathrm{NaCl}$ & IDA \\
\hline \multirow[t]{3}{*}{ MIGS-22 } & Oxygen requirement & Aerobic & IDA \\
\hline & Carbon source & Unknown & NAS \\
\hline & Energy source & Unknown & NAS \\
\hline MIGS-6 & Habitat & Human gut & IDA \\
\hline \multirow[t]{3}{*}{ MIGS-15 } & Biotic relationship & Free living & IDA \\
\hline & Pathog enicity & Unknown & NAS \\
\hline & Biosafety level & 2 & \\
\hline MIGS-14 & Isolation & Human feces & \\
\hline MIGS-4 & Geographic location & Senegal & IDA \\
\hline MIGS-5 & Sample collection time & September 2009 & IDA \\
\hline MIGS-4.1 & Latitude & 13.41 & IDA \\
\hline MIGS-4.1 & Long itude & -16.22 & IDA \\
\hline MIGS-4.3 & Depth & Surface & IDA \\
\hline MIGS-4.4 & Altitude & $<100 \mathrm{~m}$ above sea level & IDA \\
\hline
\end{tabular}

Evidence codes - IDA: Inferred from Direct Assay; TAS: Traceable Author Statement (i.e., a direct report exists in the literature); NAS: Non-traceable Author Statement (i.e., not directly observed for the living, isolated sample, but based on a generally accepted property for the species, or anecdotal evidence). These evidence codes are from the Gene Ontology project [34]. If the evidence is IDA, then the property was directly observed for a live isolate by one of the authors or an expert mentioned in the acknowledgements. 


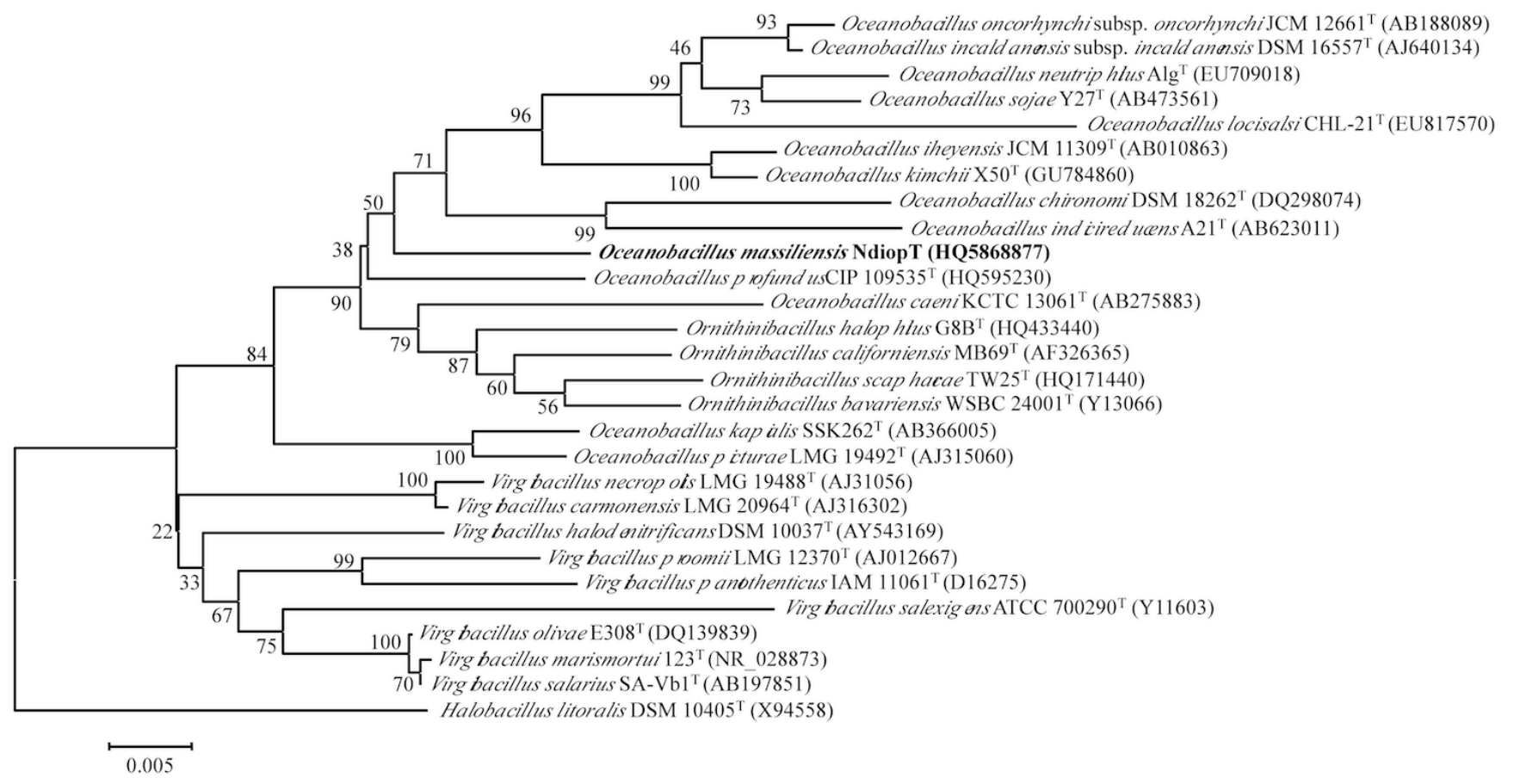

Figure 1. Phylogenetic tree highlighting the position of Oceanobacillus massiliensis strain $\mathrm{N}^{\prime} \mathrm{Diop}^{\top}$ relative to other type strains within the Oceanobacillus, Ornithinibacillus, and Virgibacillus genera. GenBank accession numbers are indicated in parentheses. Sequences were aligned using CLUSTALX, and phylogenetic inferences obtained using the neighbor joining method within the MEGA 5 software [18]. Numbers at the nodes are percentages of bootstrap values obtained by repeating the analysis 1,000 times to generate a majority consensus tree. Halobacillus litoralis was used as outg roup. The scale bar represents 0.005 nucleotide change per nucleotide position.

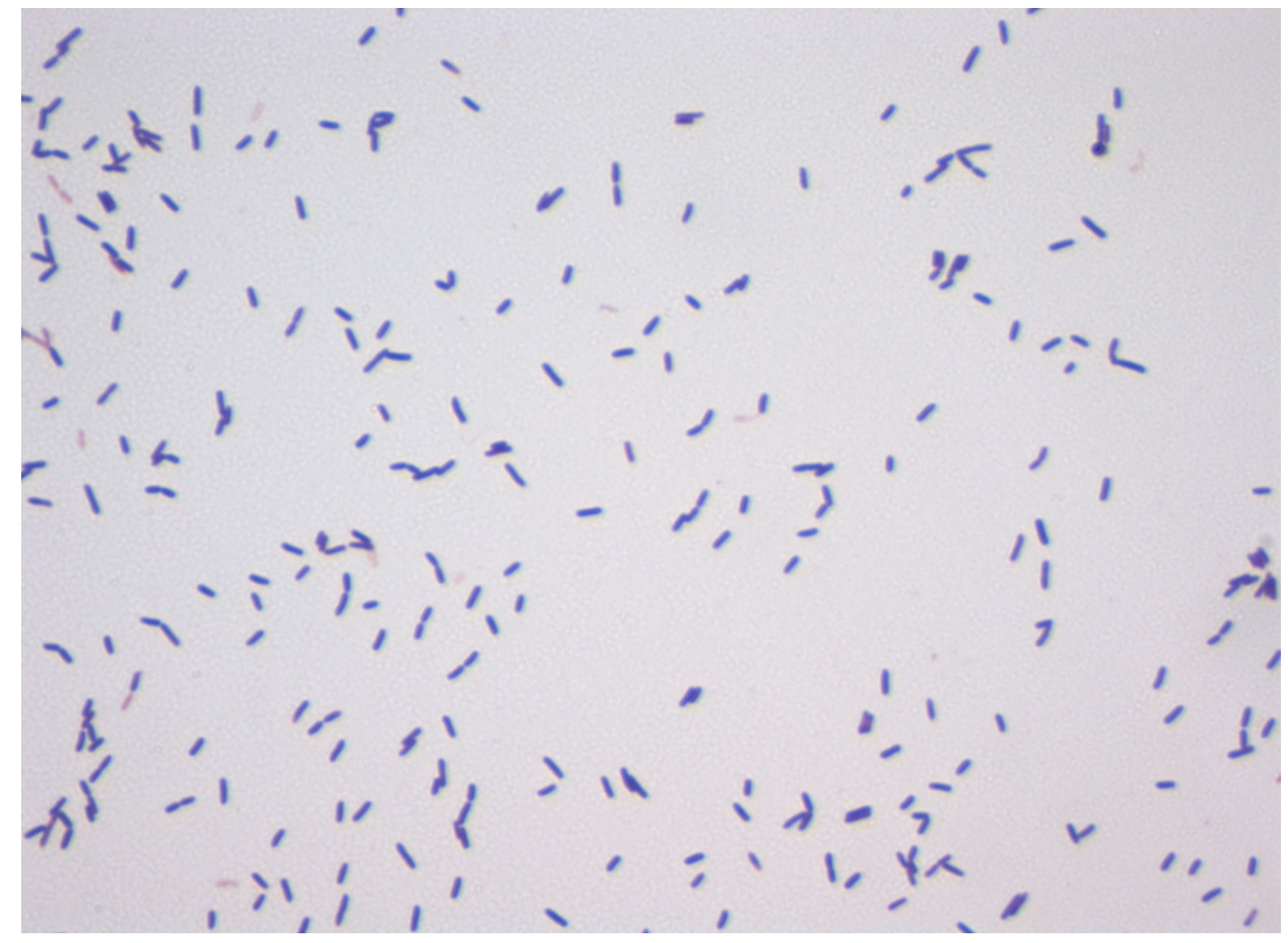

Figure 2. Gram staining of $O$. massiliens is strain $\mathrm{N}^{\prime} \mathrm{Diop}^{\top}$ 


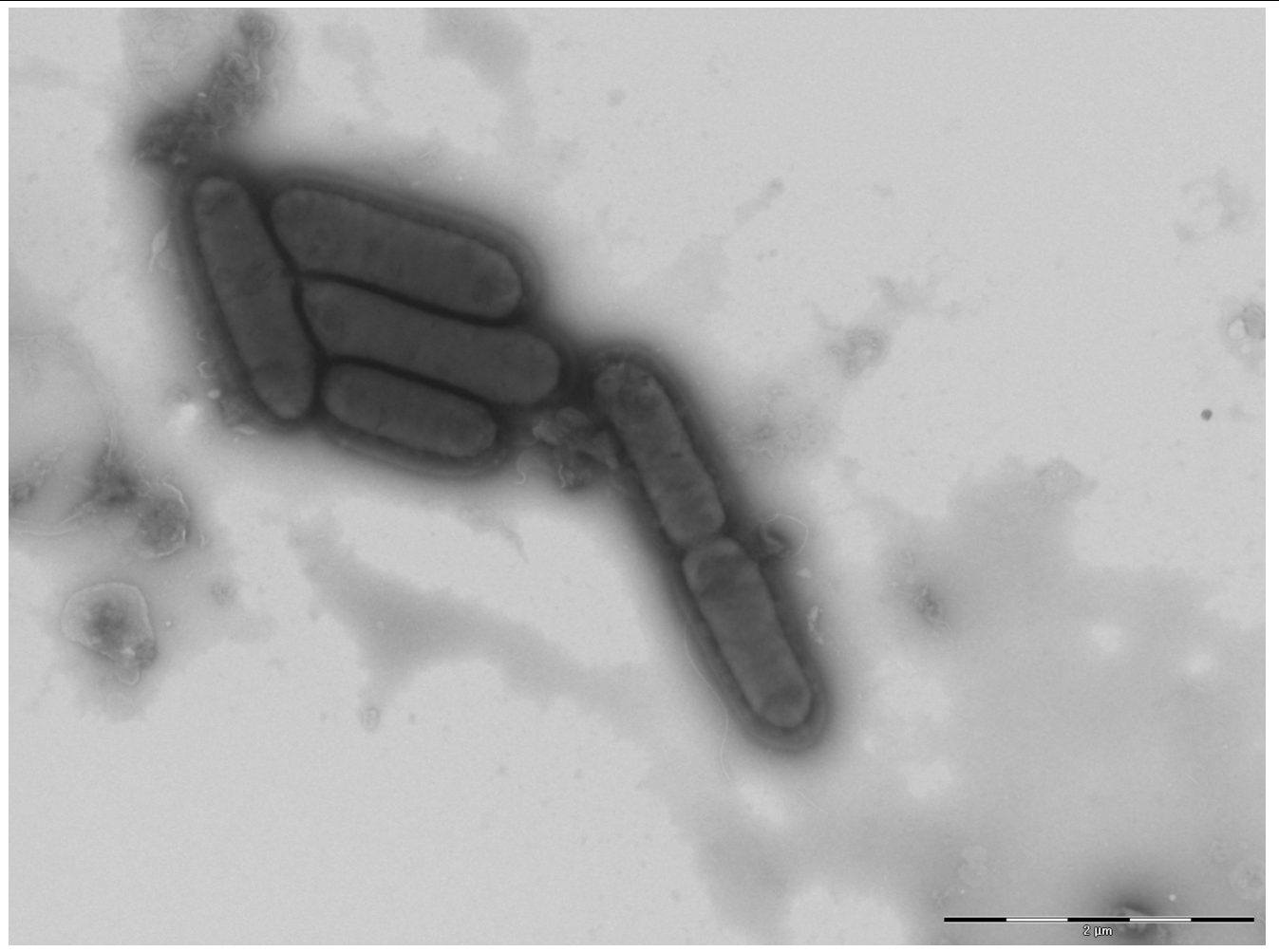

Figure 3. Transmission electron microscopy of $O$. massiliensis strain $\mathrm{N}^{\prime} \mathrm{Diop}^{\top}$, using a Morg ani 268D (Philips) at an operating voltage of $60 \mathrm{kV}$. The scale bar represents $1 \mu \mathrm{m}$.

Analysis of respiratory quinones by HPLC was carried out by the Identification Service and $\mathrm{Dr}$ Brian Tindall, DSMZ, Braunschweig, Germany. Respiratory lipoquinones were extracted from $100 \mathrm{mg}$ of freeze dried cell material as described by Tindall $[42,43]$. Respiratory lipoquinones were separated into their different classes (menaquinones and ubiquinones) by thin layer chromatography on silica gel, using hexane:terbutylmethylether $(9: 1 \mathrm{v} / \mathrm{v})$ as solvent. UV absorbing bands corresponding to menaquinones or ubiquinones were removed from the plate and further analyzed by HPLC at $269 \mathrm{~nm}$. The respiratory quinones were MK-7 (97\%) and MK6 (7\%) for strain N'Diop ${ }^{\mathrm{T}}$. Preparation and determination of cellular fatty acids were carried out by following the procedures given for the Sherlock Microbial identification System (MIDI). The major fatty acids were C15:0 anteiso $63.24 \%$ and C17:0 anteiso $26.86 \%$. The DNA base composition was determined by using the HPLC method of Mesbah et al. [44]. The value found for strain N'diop ${ }^{\mathrm{T}}$ was $40.8 \%$. Polar lipids were extracted from $100 \mathrm{mg}$ of freeze dried cell material using a chloroform:methanol:0.3\% aqueous $\mathrm{NaCl}$ mixture 1:2:0.8 (v/v/v) (modified after [45]). The extraction solvent was stirred overnight and the cell debris pelleted by centrifugation. Polar lipids were recovered into the chloroform phase by adjusting the chloroform:methanol:0.3\% aqueous $\mathrm{NaCl}$ mixture to a ratio of 1:1:0.9 (v/v/v). Polar lipids were separated as previously described [46]. The polar lipids present were diphosphatidylglycerol, phosphatidylglycerol, phospholipid 1, an unidentified aminolipid and sulfoquinovosyl diacylglycerol. The whole cells of 0 . massiliensis were hydrolyzed $\left(4 \mathrm{~N} \mathrm{HCl}, 100{ }^{\circ} \mathrm{C}\right.$, 16 hours) and the hydrolysates were subjected to thin-layer chromatography on cellulose plates using the solvent system of Rhuland et al. [47]. Mesodiaminopimelic acid (meso-Dpm) was found as diagnostic diamino acid of the peptidoglycan. The occurrence of meso-Dpm has been reported up to now only for the peptidoglycan type A1 $\gamma$ (and A1 $\gamma^{\prime}$ with glycine instead of L-alanine) and for three variations of peptidoglycan type A4y (A31.1, A31.2 and A31.3, see [48]). The variations of peptidoglycan type $\mathrm{A} 4 \gamma$ based on meso-Dpm have been found so far exclusively in members of the genera Brachybacterium, Devriesea and Dermabacter (family Dermabacteraceae). Because a close relationship between 0 . massiliensis and the family Dermabacteraceae can be ruled out, we conclude the peptidoglycan type to be A1 $\gamma$. 
Table 2. Diag nostic trait differentiation.

\begin{tabular}{|c|c|c|c|c|c|c|c|c|c|c|}
\hline Characteristic & 1 & 2 & 3 & 4 & 5 & 6 & 7 & 8 & 9 & 10 \\
\hline \multicolumn{11}{|l|}{ Assimilation of } \\
\hline Glycerol & w & w & + & + & W & - & w & - & - & - \\
\hline L-Arabinose & - & - & - & + & - & - & w & - & - & - \\
\hline Ribose & - & + & - & + & - & - & - & - & - & - \\
\hline D-Xylose & + & + & - & + & - & - & w & - & - & - \\
\hline Methyl-ßDXylopyranosi de & - & - & - & + & - & - & - & - & - & - \\
\hline D-Galactose & - & - & + & + & - & - & - & - & - & - \\
\hline D-Glucose & + & + & + & + & W & - & w & - & - & - \\
\hline D-Fructose & + & + & + & + & W & - & w & - & - & - \\
\hline D-Mannose & + & + & + & + & w & - & w & - & - & - \\
\hline L-Sorbose & - & - & + & - & - & - & - & - & - & - \\
\hline Dulcitol & - & - & + & + & - & - & - & - & - & - \\
\hline Inositol & - & - & + & + & - & - & - & - & - & - \\
\hline D-Mannitol & + & + & + & + & - & - & - & - & - & - \\
\hline Methyl-aDMannopyranoside & - & - & - & - & - & - & w & - & - & - \\
\hline Methyl-aDGlucopyranoside & - & - & + & + & - & - & w & - & - & - \\
\hline N-Acetylg lucosamine & + & + & + & + & w & - & w & - & - & - \\
\hline Amyg dalin & - & + & + & + & - & - & - & - & - & - \\
\hline Arbutin & - & - & + & + & - & - & - & - & - & - \\
\hline Salicin & + & + & + & + & - & - & w & - & - & - \\
\hline D-Cellobiose & + & + & + & + & - & - & w & - & - & - \\
\hline D-Maltose & + & + & + & + & - & - & w & - & - & - \\
\hline D-Saccharose & - & + & + & + & - & - & - & - & - & - \\
\hline D-Trehalose & + & + & + & + & - & - & - & - & - & - \\
\hline D-Raffinose & - & - & + & + & - & - & - & - & - & - \\
\hline Gentiobiose & - & - & + & + & - & - & - & - & - & - \\
\hline D-Turanose & - & - & + & + & - & - & - & - & - & - \\
\hline D-Tagatose & - & + & + & + & - & - & - & - & - & - \\
\hline D-Arabitol & - & w & w & w & - & - & - & - & - & - \\
\hline potassium Gluconate & - & - & w & w & - & + & - & - & - & - \\
\hline Reduction of nitrates to nitrites & - & + & + & + & - & & & & & \\
\hline Urease & - & + & - & - & - & - & - & - & - & - \\
\hline Esculin hydrolysis & + & + & + & + & - & + & - & - & - & - \\
\hline Para-nitrophenyl- $\beta$ Dg alactopyranosidase & - & w & - & w & - & + & w & - & + & + \\
\hline Esterase (C4) & + & + & + & + & + & + & + & - & - & - \\
\hline Esterase lipase (C8) & + & + & + & + & w & + & w & w & w & + \\
\hline Leucine arylaminidase & - & - & - & - & w & w & - & + & w & - \\
\hline$\alpha$-chemotrypsin & - & - & w & - & - & - & w & - & - & - \\
\hline$\beta$-glucuronidase & - & + & - & - & - & - & - & + & + & - \\
\hline$\beta$-glucosidase & + & - & + & - & - & & - & - & - & - \\
\hline
\end{tabular}

Strains: 1, O. massiliensis sp. nov. NdiopT; 2, O. profundus CIP 109535T; 3, O. oncorhynchi subsp. oncorhynchi CIP 108867T; 4, O. oncorhynchi subsp. incaldanensis CIP 109235T; 5, O. iheyensis CIP 107618T; 6, O. chironomi CIP109536T ; 7, O. picturae CIP 108264T; 8, Ornithinibacillus bavariensis DSM 15681T; 9, Ornithinibacillus californiensis DSM 16628T; 10, Ornithinibacillus contaminans DSM 22953 T.

+: positive result, -: negative result, w: weak positive result 
Antimicrobial susceptibility was determined according to the National Committee for Clinical Laboratory Standards (NCCLS) criteria. Strain N'diop ${ }^{T}$ was found to be susceptible to doxycycline, rifampicine, vancomycine, nitrofurantoin, amoxicillin, erythromycin, ampicillin, ceftriaxone, ciprofloxacine, gentamycine, penicilline, imipenem. But it was resistant to trimethoprim/sulfamethoxazole and metronidazole.

Matrix-assisted laser-desorption/ionization timeof-flight (MALDI-TOF) MS protein analysis was carried out. Briefly, a pipette tip was used to pick one isolated bacterial colony from a culture agar plate, and to spread it as a thin film on a MALDI-TOF target plate (Bruker Daltonics). Twelve distinct deposits were done for strain $\mathrm{N}^{\prime} \mathrm{Diop}^{\mathrm{T}}$ from twelve isolated colonies and the manipulation was repeated another day. After air-drying, $1.5 \mu \mathrm{l}$ matrix solution (saturated solution of $\alpha$-cyanohydroxycinnaminic acid in 50\% aqueous acetonitrile containing 2.5\% trifluoroacetic acid) per spot was applied. MALDITOF MS was conducted using the Microflex LT spectrometer (Bruker Daltonics). All spectra were recorded in linear, positive ion mode. The acceleration voltage was $20 \mathrm{kV}$. Spectra were collected as a sum of 240 shots across a spot. Preprocessing and identification steps were performed using the manufacturer's parameters. The N'Diop ${ }^{T}$ spectra were imported into the MALDI BioTyper software (version 3.0, Bruker) and analyzed by standard pattern matching (with default parameter settings) against the main spectra of 4,108 bacteria including the spectra from Oceanobacillus profundus CIP 109535', Oceanobacillus picturae CIP 108264T, Oceanobacillus chironomi CIP 109536', Oceanobacillus iheyensis CIP 107618', Oceanobacillus oncorhynchi subsp. oncorhynchi CIP 108867T and Oceanobacillus oncorhynchi subsp incaldanensis CIP $109235^{\mathrm{T}}$ which were the most closely related species when 16S rRNA gene sequences were compared and Ornithinibacillus bavariensis DSM 15681 ${ }^{\mathrm{T}}$, Ornithinibacillus californiensis DSM $16628^{\mathrm{T}}$ and Ornithinibacillus contaminans DSM 22953', used as reference data, in the BioTyper database. A score enabled the identification, or not, from the tested species: a score > 2.3 with a validated species enabled the identification at the species level, a score $>1.7$ but $<2$ enabled the identification at the genus level; and a score $<1.7$ did not enable any identification. For strain $\mathrm{N}^{\prime} \mathrm{Diop}^{\mathrm{T}}$, none of the obtained scores were $>$ 1.5 , thus suggesting that our isolate was not a member of a known species. We incremented our database with the spectrum from strain N'Diop ${ }^{\mathrm{T}}$ (Figure 4). The spectrum was made available online in our free-access URMS database [49].
Oceanobacilhs picturae
Oceanobacilhus oncorhynchi sub
Oceanobacillus oncorhynchi sub
Oceanobacillus iheyensis
Oceanobacillus chironomi
Oceanobacillus profundus
Oceanobacillus massiliensis
Ornithinibacillus bavariensis
Ornithinibacillus californiensis
Ornithinibacillus contaminans

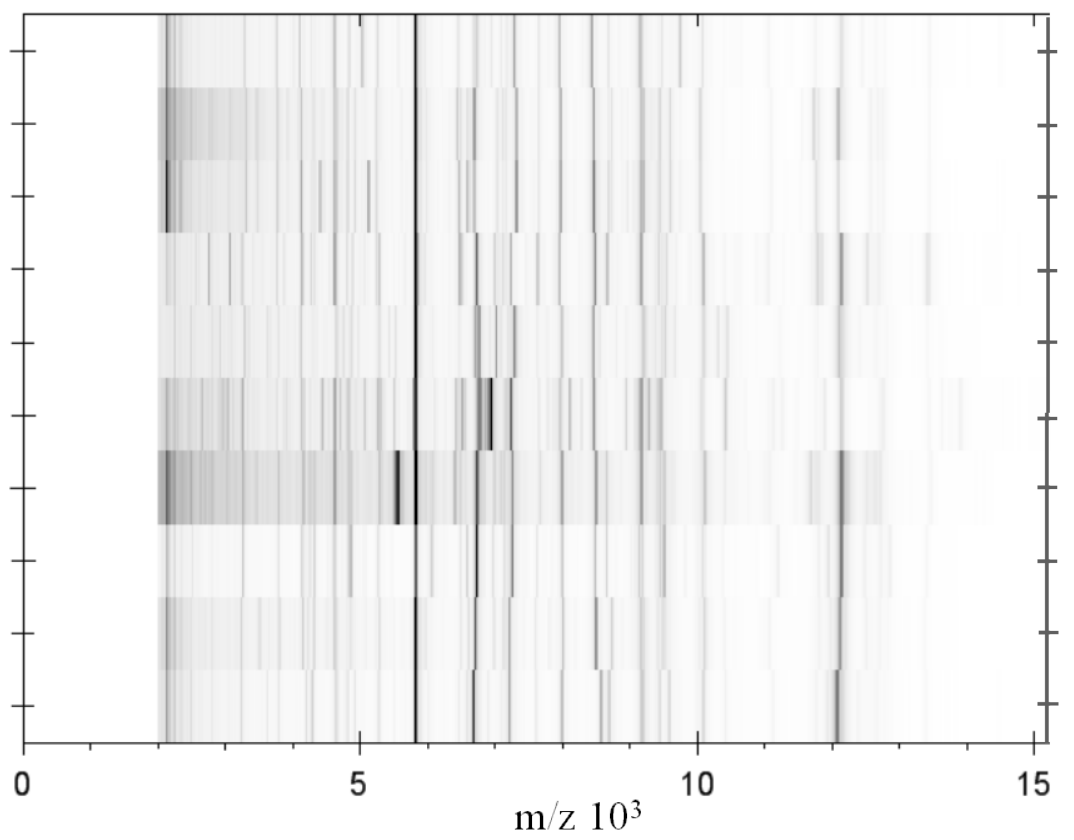

$\mathrm{m} / \mathrm{z} 10^{3}$

Figure 4. Reference mass spectra from $O$. massiliensis strain $\mathrm{N}^{\prime} \mathrm{Diop}^{\top}$, other representatives of the genus Oceanobacillus and type strains of the genus Ornithinibacillus. Spectra from 24 individual colonies were compared and a reference spectrum was generated. 


\section{Genome sequencing information}

\section{Genome project history}

The organism was selected for sequencing on the basis of its phylogenetic position and 16S rRNA similarity to other members of the genus Oceanobacillus, and is part of a "culturomics" study of the human digestive flora aiming at isolating all bacterial species within human feces. It was the second sequenced genome of an Oceanobacillus species, Oceanobacillus massiliensis sp. nov. A summary of the project information is shown in Table 3. The EMBL accession number is CAER01000000 and consists of 95 contigs ( $\geq 500$ bp) and 9 scaffold ( $>2,500 \mathrm{bp}$ ). Table 2 shows the project information and its association with MIGS version 2.0 compliance.

\section{Growth conditions and DNA isolation}

O. massiliensis sp. nov. strain N'Diop ${ }^{\mathrm{T}}$, CSUR P132T, DSM 24644T, was grown aerobically on 5\% sheep blood-enriched Columbia agar at $37^{\circ} \mathrm{C}$. Three petri dishes were spread and resuspended in $3 \times 100 \mu \mathrm{l}$ of G2 buffer. A first mechanical lysis was performed by glass powder on the Fastprep-24 device (Sample Preparation system) from MP Biomedicals, USA during 2x20 seconds. DNA was then incubated for a lysozyme treatment (30 minutes at $37^{\circ} \mathrm{C}$ ) and extracted through the BioRobot EZ 1 Advanced XL (Qiagen). The DNA was then concentrated and purified on a Qiamp kit
(Qiagen). The yield and the concentration were measured by the Quant-it Picogreen kit (Invitrogen) on the Genios Tecan fluorometer at 139 $\mathrm{ng} / \mu \mathrm{l}$.

\section{Genome sequencing and assembly}

Shotgun and 3-kb paired-end sequencing strategies were performed. The shotgun library was constructed with 500 ng of DNA with the GS Rapid library Prep kit (Roche). For the paired-end sequencing, $5 \mu \mathrm{g}$ of DNA was mechanically fragmented on a Hydroshear device (Digilab) with an enrichment size at 3-4 kb. The DNA fragmentation was visualized using the 2100 BioAnalyzer (Agilent) on a DNA labchip 7500 with an optimal size of $3.1 \mathrm{~kb}$. The library was constructed according to the 454 GS FLX Titanium paired-end protocol. Circularization and nebulization were performed and generated a pattern with an optimal size of 450 bp. After PCR amplification through 17 cycles followed by double size selection, the single stranded paired-end library was then quantified using the Genios fluorometer (Tecan) at $220 \mathrm{pg} / \mu \mathrm{L}$. The library concentration equivalence was calculated as $8.97 \mathrm{E}+08$ molecules/ $\mu \mathrm{L}$. The library was stored at $-20^{\circ} \mathrm{C}$ until further use.

Table 3. Project information

\begin{tabular}{|c|c|c|}
\hline MIGS ID & Property & Term \\
\hline MIGS-31 & Finishing quality & High-quality draft \\
\hline MIGS-28 & Libraries used & One paired end 3-kb library and one Shotg un library \\
\hline MIGS-29 & Sequencing platforms & 454 GS FLX Titanium \\
\hline MIGS-31.2 & Fold coverage & $23 x$ \\
\hline MIGS-30 & Assemblers & Newbler version 2.5.3 \\
\hline \multirow[t]{4}{*}{ MIGS-32 } & Gene calling method & Prodigal \\
\hline & EMBL ID & CAER01000000 \\
\hline & EMBL Date of Release & February 28,2013 \\
\hline & Project relevance & Study of the human gut microbiome \\
\hline
\end{tabular}


The shotgun and paired-end libraries were clonally-amplified with $3 \mathrm{cpb}$ and $1 \mathrm{cpb}$ in 3SV-emPCR reactions respectively on the GS Titanium SV emPCR Kit (Lib-L) v2 (Roche). The yields of the emPCR were $15.1 \%$ and $12.1 \%$ respectively. Approximately 790,000 beads for the shotgun application and for the $3 \mathrm{~kb}$ paired end were loaded on the GS Titanium PicoTiterPlate PTP Kit 70x75 and sequenced with the GS FLX Titanium Sequencing Kit XLR70 (Roche). The run was performed overnight and then analyzed on the cluster through the gsRunBrowser and Newbler assembler (Roche). A total of 279,999 passed filter wells were obtained and generated $81 \mathrm{Mb}$ with a length average of 289 bp. The passed filter sequences were assembled using Newbler with $90 \%$ identity and $40 \mathrm{bp}$ as overlap. The final assembly identified 9 scaffolds and large 82 contigs ( $>1,500 \mathrm{bp}$ ).

\section{Genome annotation}

Open Reading Frames (ORFs) were predicted using Prodigal [50] with default parameters but the predicted ORFs were excluded if they were spanning a sequencing GAP region. The predicted bacterial protein sequences were searched against the GenBank database [51] and the Clusters of Orthologous Groups (COG) databases [52] using BLASTP. The tRNAscan-SE tool [53] was used to find tRNA genes, whereas ribosomal RNAs were found by using RNAmmer [54].

Transmembrane domains and signal peptides were predicted using TMHMM [55] and SignalP [56], respectively. ORFans were identified if their BLASTp $E$-value was lower than 1e-03 for alignment length greater than 80 amino acids. If alignment lengths were smaller than 80 amino acids, we used an $E$-value of $1 \mathrm{e}-05$. Such parameter thresholds have been used in previous works to define ORFans.

To estimate the mean level of nucleotide sequence similarity at the genome level between 0 . massiliensis and 0 . iheyensis (GenBank accession number PRJNA57867), the only available Oceanobacillus genome to date, we compared the ORFs only using comparison sequence based in the server RAST [57] at a query coverage of $\geq 70 \%$ and a minimum nucleotide length of $100 \mathrm{bp}$.

\section{Genome properties}

The genome is 3,532,675 bp long with $40.35 \%$ GC content (Table 4 and Figure 5). It is composed of 95 Contigs ( 9 Scaffolds). Of the 3,589 predicted genes, 3,519 were protein-coding genes, and 72 were RNAs (1 gene is $16 \mathrm{~S}$ rRNA, 1 gene is $23 \mathrm{~S}$ rRNA, 9 genes are 5S rRNA, and 61 are tRNA genes). A total of 2,536 genes (72.07\%) were assigned a putative function (by cogs or by NR blast). In addition, 84 genes were identified as ORFans (2.39\%). The remaining genes were annotated as hypothetical proteins (618 genes $(17.56 \%))$. The distribution of genes into COGs functional categories is presented in Table 5. The properties and the statistics of the genome are summarized in Tables 4 and 5. Two CRISPRs were found using CRISPERfinder program online [58] which included at least 48 predicted spacer regions (contigs 39-41) and 13 predicted spacer regions (contig 92).

\begin{tabular}{lrr}
\multicolumn{3}{l}{ Table 4. Nucleotide content and gene count levels of the genome } \\
\hline Attribute & Value & \% of $_{\text {total }}^{\mathbf{a}}$ \\
\hline Genome size (bp) & $3,532,675$ & 100 \\
DNA coding region (bp) & $2,971,565$ & 84,12 \\
DNA G+C content (bp) & $1,425,470$ & 40,35 \\
Total genes & 3,589 & 100 \\
RNA genes & 72 & 1.95 \\
Protein-coding genes & 3,519 & 98.05 \\
Genes with function prediction & 2,536 & 72.07 \\
Genes assig ned to COGs & 2,673 & 75.96 \\
Genes with peptide signals & 348 & 9.89 \\
Genes with transmembrane helices & 885 & 25.15 \\
\hline
\end{tabular}

a) The total is based on either the size of the genome in base pairs or the total number of protein coding genes in the annotated genome. 


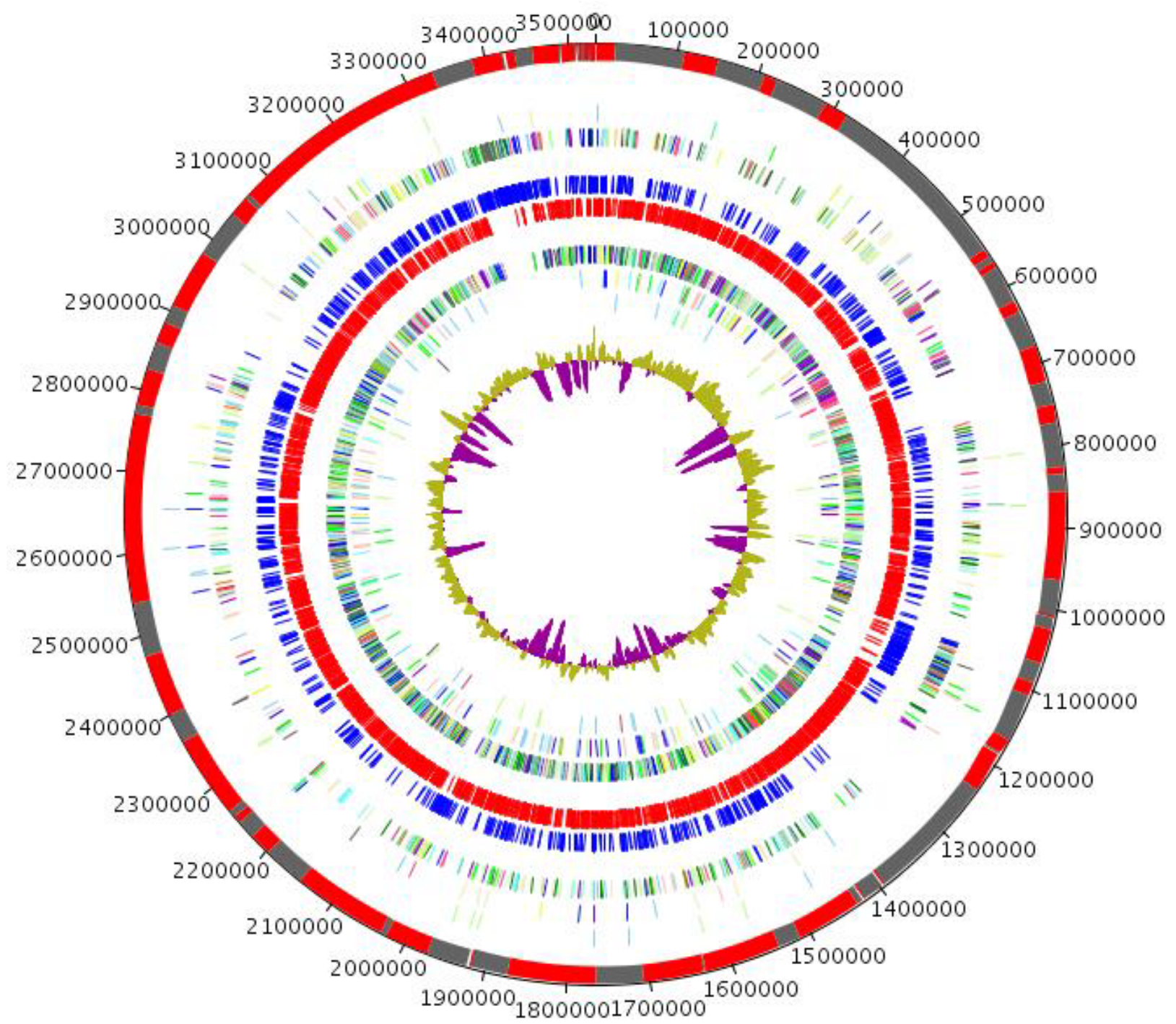

Figure 5. Graphical circular map of the $O$. massiliensis strain $N^{\prime}$ Diop genome. From outside to the center. Contigs (red / g rey), COG category of genes on the forward strand (three circles), genes on forward strand (blue circle), genes on the reverse strand (red circle), COG category on the reverse strand (three circles), $\mathrm{G}+\mathrm{C}$ content.

\section{Comparison with other Oceanobacillus genomes}

To date, only one genome of bacteria belonging to the genus Oceanobacillus was sequenced, Oceanobacillus iheyensis. By comparison with the genome of 0 . iheyensis, 0 . massiliensis had a smaller genome (3.53 vs $3.63 \mathrm{Mb}$, respectively), a higher $\mathrm{G}+\mathrm{C}$ content (40.35 vs $35.7 \%$ ) but a smaller number of predicted genes $(3,589$ vs 3,593 genes). In addition, 0 . massiliensis and 0 . iheyensis shared a mean nucleotide sequence similarity of $80.49 \%$ at the genome level (range 70.03-98.32\%).

\section{Prophage genome properties}

Prophage Finder [59] was used to identify potential proviruses in 0 . massiliensis strain $\mathrm{N}^{\prime} \mathrm{Diop}^{\mathrm{T}}$ genome. The genome contains at least one genetic element of around $48.9 \mathrm{~kb}$ (with a GC content of $38.9 \%$ ), we named OM1, on contig 65 . A total of 51 open reading frames (ORFs) were recovered from OM1, larger than 160 nucleotides and most of them (42) encode proteins sharing a high identity with proteins found in Clostridiales genus viruses. The preliminary annotation of OM1 was performed and the majority of the putative genes (31) encode hypothetical proteins. The ORFs with an attributed function (21) encode proteins involved in DNA packaging, cell lysis, tail structural components and assembly, head structural components and assembly, lysogeny control, DNA replication, recombination and modification. Fifty one of the ORFs are located on one strand and 1 on the opposite strand. 
Table 5. Number of genes associated with the 25 general COG functional categ ories

\begin{tabular}{crrl}
\hline Code & Value & \%age & Description \\
\hline J & 170 & 4.83 & Translation \\
A & 0 & 0 & RNA processing and modification \\
K & 232 & 6.59 & Transcription \\
L & 184 & 5.23 & Replication, recombination and repair \\
B & 1 & 0.03 & Chromatin structure and dynamics \\
D & 37 & 1.05 & Cell cycle control, mitosis and meiosis \\
Y & 0 & 0 & Nuclear structure \\
V & 48 & 1.36 & Defense mechanisms \\
T & 142 & 4.04 & Signal transduction mechanisms \\
M & 156 & 4.43 & Cell wall/membrane biog enesis \\
N & 64 & 1.82 & Cell motility \\
Z & 0 & 0 & Cytoskeleton \\
W & 0 & 0 & Extracellular structures \\
U & 52 & 1.48 & Intracellular trafficking and secretion \\
O & 104 & 2.96 & Posttranslational modification, protein turnover, chaperones \\
C & 149 & 4.23 & Energy production and conversion \\
G & 194 & 5.51 & Carbohydrate transport and metabolism \\
E & 283 & 8.04 & Amino acid transport and metabolism \\
F & 84 & 2.39 & Nucleotide transport and metabolism \\
H & 100 & 2.84 & Coenzyme transport and metabolism \\
I & 84 & 2.39 & Lipid transport and metabolism \\
P & 224 & 6.37 & Inorganic ion transport and metabolism \\
Q & 54 & 1.53 & Secondary metabolites biosynthesis, transport and catabolism \\
R & 424 & 12.05 & General function prediction only \\
S & 281 & 7.99 & Function unknown \\
X & 846 & 24.04 & Not in COGs \\
\hline & & & \\
\hline
\end{tabular}

a) The total is based on the total number of protein coding genes in the annotated genome.

\section{Conclusion}

Bacteria included in genera Oceanobacillus and Ornithinibacillus are closely related. The inclusion of these genera is based only on the isoc15:0/anteiso-c15:0 ratio ( $>1$ for the Ornithinibacillus genus and $<1$ for the Oceanobacillus genus) and the peptidoglycan type (A4 $\beta$ for the Ornithinibacillus genus and $A 1 \gamma$ for the genus Oceanobacillus genus). All the other criteria proposed are not valid for all the representatives of the genus, or can be discordant when manipulations are performed in different laboratories.
On the basis of phenotypic, phylogenetic and genomic analyses, we propose the creation of Oceanobacillus massiliensis sp. nov. that contains the strain N'Diop ${ }^{\mathrm{T}}$. This bacterium has been found in Senegal.

In the future, sequencing and comparison of several genomes of Oceanobacillus and Ornithinibacillus representatives will allow better understanding of these taxa. 
Description of Oceanobacillus massiliensis sp. nov. Oceanobacillus massiliensis (mas.si.li.en'sis. L. masc. adj. massiliensis of Massilia, the old Roman name for Marseille, where the type strain was isolated). Cells are aerobic, Gram-positive, straight, and motile rods. Catalase-positive and oxidasepositive. Growth occurred in aerobic conditions. Optimal growth occurs at $30-37{ }^{\circ} \mathrm{C}$, pH 7-8 and $\mathrm{NaCl}$ range of $0,5-5 \%$. After 24 hours growth on sheep blood agar, surface colonies are up to 2-5 $\mathrm{mm}$ in diameter, smooth, circular, greyish and shiny. The rods measure 1.2-1.9 $\mu \mathrm{m}$ in length and 0.4-0.7 $\mu \mathrm{m}$ in diameter (as determined by electron microscopy). Using Api ZYM, activities of esterase (C4), esterase lipase (C8) and $\alpha$-glucosidase are detected. Activities of alkaline phosphatase, lipase (C14), leucine arylaminidase, valine arylaminidase, cystine arylaminidase, trypsin, $\alpha$-chemotrypsin, acid phosphatase, naphthol-AS-BIphosphohydrolase, $\quad \beta$-galactosidase, $\quad \beta$ glucuronidase, $\beta$ - glucosidase, $N$-acetyl- $\beta$ glucosaminidase, $\alpha$-mannosidase and $\alpha$-fucosidase are not detected. Using Api 50CH strips after an incubation time of $48 \mathrm{~h}$ acid is produced from glycerol (weakly), D-xylose, D-glucose, D-fructose, Dmannose, D-mannitol, N- acetylglucosamine, esculin ferric citrate, salicin, D-cellobiose, Dmaltose and D-trehalose. Acid is not produced from

\section{Acknowledgements}

The authors thank Julien Paganini at Xegen Company (www.xegen.fr) for automating the genomic annotation process.

\section{References}

1. Lagier JC, Armoug om F, Million M, Hug on P, Pagnier I, Robert C, Bittar F, Fournous G, Gimenez G, Maraninchi M, et al. Microbial culturomics: paradig $m$ shift in the human gut microbiome study. Clin Microbiol Infect 2012; 18:1185-1193. PubMed

2. Rossello-Mora R. DNA-DNA reassociation methods applied to microbial taxonomy and their critical evaluation. In: Stackebrandt E (ed), Molecular Identification, Systematics, and population Structure of Prokaryotes, Spring er, Berlin, 2006, p. 2350.

3. Wayne LG, Brenner DJ, Colwell RR, Grimont PAD, Kandler O, Krichevsky MI, Moore LH, Moore WEC, Murray RGE, Stackebrandt E, et al. Report of the ad hoc committee on reconciliation of approaches to bacterial systematics. Int J Syst erythitol, D-arabinose, L-arabinose, D-ribose, Lxylose, D-adonitol, methyl- $\beta \mathrm{D}$-xylopyranoside, Dgalactose, L-sorbose, L-rhamnose, dulcitol, inositol, D-sorbitol, methyl- $\alpha$ D-mannopyranoside, methyl$\alpha \mathrm{D}$-glucopyranoside, amygdalin, arbutin, D-lactose, D-melibiose, D-saccharose, inulin, D-melezitose, Draffinose, amidon, glycogen, xylitol, gentiobiose, Dturanose, D-lyxose, D-tagatose, D-fucose, L-fucose, D-arabinol, L-arabinol, potassium gluconate, potassium 2-ketogluconate and potassium 5ketogluconate. Using Api $20 \mathrm{NE}$, hydrolysis of esculine is positive. Nitrate reduction, indole production, glucose fermentation, arginine dihydrolase, urease, gelatin hydrolysis and $\beta$ galactosidase are negative.

The respiratory quinones are MK-7 (93\%) and MK$6(7 \%)$. The major fatty acids are C15:0 anteiso (63.24\%) and C17:0 anteiso (26.86\%). The $\mathrm{G}+\mathrm{C}$ content of the genomic DNA is $40.35-40.8 \%$.

The type strain, which was isolated from human feces, is N'diop'T. It has been deposited in the Collection de Souches de l'Unité des Rickettsies, Marseille, France, as CSUR P132 ${ }^{\mathrm{T}}$ and in the Leibniz Institute DSMZ-German Collection of Microorganisms and Cell Cultures, as DSM 24644T.

Bacteriol 1987; 37:463-464. http://dx.doi.org/10.1099/00207713-37-4-463

4. Tindall BJ, Rossello-Mora R, Busse HJ, Ludwig W, Kämpfer P. Notes on the characterization of prokaryote strains for taxonomic purposes. Int / Syst Evol Microbiol 2010; 60:249-266. PubMed http://dx.doi.org/10.1099/ijs.0.016949-0

5. Lu J, Nogi Y, Takami H. Oceanobacillus iheyensis gen. nov., sp. nov., a deep-sea extremely halotolerant and alkaliphilic species isolated from a depth of $1050 \mathrm{~m}$ on the Iheya Ridge. FEMS Microbiol Lett 2001; 205:291-297. PubMed http://dx.doi.org/10.1111/j.15746968.2001.tb10963.x

6. Yumoto I, Hirota K, Nodasaka Y, Nakajima K. Oceanobacillus oncorhynchisp. nov., a halotolerant obligate alkaliphile isolated from the 
skin of a rainbow trout (Oncorhynchus mykiss), and emended description of the genus Oceanobacillus. Int J Syst Evol Microbiol 2005; 55:1521-1524. PubMed http://dx.doi.org/10.1099/ijs.0.63483-0

7. Kim YG, Choi DH, Hyun S, Cho BC. Oceanobacillus profundus sp. nov., isolated from a deep-sea sediment core. Int / Syst Evol Microbiol 2007; 57:409-413. PubMed http://dx.doi.org/10.1099/ijs.0.64375-0

8. Heyrman J, Logan NA, Busse HJ, Balcaen A, Lebbe L, Rodriguez-Diaz M, Swings J, De Vos P. Virgibacillus carmonens is sp. nov., Virgibacillus necropolis sp. nov. and Virgibacillus picturae sp. nov., three novel species isolated from deteriorated mural paintings, transfer of the species of the genus Salibacillus to Virgibacillus, as Virgibacillus marismortui comb. nov. and Virgibacillus salexigens comb.nov., and emended description of the genus Virgibacillus. Int I Syst Evol Microbiol 2003; 53:501-511. PubMed http://dx.doi.org/10.1099/ijs.0.02371-0

9. Lee JS, Lim JM, Lee KC, Lee JC, Park YH, Kim CJ. Virgibacillus koreens is sp. nov., a novel bacterium from salt field, and transfer of Virgibacillus picturae to the genus Oceanobacillus as Oceanobacillus picturae comb. nov. with emended descriptions. Int J Syst Evol Microbiol 2006;

56:251-257. PubMed http://dx.doi.org/10.1099/ijs.0.63734-0

10. Yumoto I, Hirota K, Nodasaka Y, Nakajima K. Oceanobacillus oncorhynchisp. nov., a halotolerant obligate alkaliphile isolated from the skin of a rainbow trout (Oncorhynchus mykiss), and emended description of the genus Oceanobacillus. Int J Syst Evol Microbiol 2005; 55:1521-1524. PubMed http://dx.doi.org/10.1099/ijs.0.63483-0

11. Romano I, Lama L, Nicolaus B, Poli A, Gambacorta A, Giordano A. Oceanobacillus oncorhynchi subsp. incaldanensis subsp. nov, an alkalitolerant halophile isolated from an algal mat collected from a sulfurous spring in Campania (Italy), and emended description of Oceanobacillus oncorhynchi. Int I Syst Evol Microbiol 2006;

56:805-810. PubMed http://dx.doi.org/10.1099/ijs.0.63575-0

12. Raats D, Halpern M. Oceanobacillus chironomi sp. nov., a halotolerant and facultatively alkaliphilic species isolated from a chironomid egg mass. Int J Syst Evol Microbiol 2007; 57:2 55259. PubMed http://dx.doi.org/10.1099/ijs.0.64502-0
13. Nam JH, Bae W, Lee DH. Oceanobacillus caeni sp. nov., isolated from a Bacillus-dominated wastewater treatment system in Korea. Int I Syst Evol Microbiol 2008; 58:1109-1113. PubMed http://dx.doi.org/10.1099/ijs.0.65335-0

14. Namwong S, Tanasupat $S$, Lee KC, Lee JS. Oceanobacillus kapialis sp. nov., from fermented shrimp paste in Thailand. Int / Syst Evol Microbiol 2009; 59:22 54-22 59. PubMed http://dx.doi.org/10.1099/ijs.0.007161-0

15. Tominaga T, An SY, Oyaizu H, Yokota A. Oceanobacillus soja sp. nov. isolated from soy sauce production equipment in Japan. Int J Syst Evol Microbiol 2009; 55:225-2 32.

16. Lee SY, Oh TK, Kim W, Yoon JH. Oceanobacillus locisalsisp. nov., isolated from a marine solar saltern of the Yellow Sea, Korea. Int J Syst Evol Microbiol 2010; 60:2 758-2 762. PubMed http://dx.doi.org/10.1099/ijs.0.021907-0

17. Whon TW, Jung MJ, Roh SW, Nam YD, Park EJ, Shin KS, Bae JW. Oceanobacillus kimchii sp. nov. isolated from a traditional Korean fermented food. J Microbiol 2010; 48:862-866. PubMed http://dx.doi.org/10.1007/s12275-010-0214-7

18. Hirota K, Aino K, Nodasaka Y, Yumoto I. Oceanobacillus indicireducens sp. nov., a facultative alkaliphile that reduces an indigo dye. Int J Syst Evol Microbiol 2013; 63:1437-1442. PubMed http://dx.doi.org/10.1099/ijs.0.034579-0

19. Yang JY, Huo YY, Xu XW, Meng FX, Wu M, Wang CS. Oceanobacillus neutriphilus sp. nov., isolated from activated sludge in a bioreactor. Int J Syst Evol Microbiol 201 0; 60:2 409-2414. PubMed http://dx.doi.org/10.1099/ijs.0.016295-0

20. Field D, Garrity G, Gray T, Morrison N, Seleng ut J, Sterk P, Tatusova T, Thomson N, Allen MJ, Angiuoli SV, et al. The minimum information about a genome sequence (MIGS) specification. Nat Biotechnol 2008; 26:541-547. PubMed http://dx.doi.org/10.1038/nbt1360

21. Woese CR, Kandler O, Wheelis ML. Towards a natural system of organisms: proposal for the domains Archaea, Bacteria, and Eucarya. Proc Natl Acad Sci USA 1990; 87:4576-4579. PubMed http://dx.doi.org/10.1073/pnas.87.12.4576

22. Murray RGE. The Higher Taxa, or, a Place for Everything...? In: Holt JG (ed), Bergey's Manual of Systematic Bacteriology, First Edition, Volume 1, The Williams and Wilkins Co., Baltimore, 1984, p. 31-34. 
23. Garrity GM, Holt JG. The Road Map to the Manual. In: Garrity GM, Boone DR, Castenholz RW (eds), Bergey's Manual of Systematic Bacteriology, Second Edition, Volume 1, Springer, New York, 2001, p. 119-169.

24. Gibbons NE, Murray RGE. Proposals Concerning the Higher Taxa of Bacteria. Int I Syst Bacteriol 1978; 28:1-6.

http://dx.doi.org/10.1099/00207713-28-1-1

25. Ludwig W, Schleifer KH, Whitman WB. Class I. Bacilli class nov. In: De Vos P, Garrity G, Jones D, Krieg NR, Ludwig W, Rainey FA, Schleifer KH, Whitman WB (eds), Bergey's Manual of Systematic Bacteriology, Second Edition, Volume 3, Spring er-Verlag, New York, 2009, p. 19-20.

26. Euzéby J. List of new names and new combinations previously effectively, but not validly, published. List no. 132. Int J Syst Evol Microbiol 2010; 60:469-472. http://dx.doi.org/10.1099/ijs.0.022855-0

27. Prévot AR. In: Hauderoy P, Ehringer G, Guillot $G$, Magrou. J., Prévot AR, Rosset D, Urbain A (eds), Dictionnaire des Bactéries Pathogènes, Second Edition, Masson et Cie, Paris, 1953, p. 1-692.

28. Skerman VBD, McGowan V, Sneath PHA. Approved Lists of Bacterial Names. Int J Syst Bacteriol 1980; 30:225-420. http://dx.doi.org/10.1099/00207713-30-1-225

29. Fischer A. Untersuchungen über bakterien. Jahrbücher für Wissenschaftliche Botanik 1895; 27:1-163.

30. List Editor. Validation List no. 85. Validation of publication of new names and new combinations previously effectively published outside the IJSEM. Int J Syst Evol Microb iol 2002; 52:685-690. PubMed http://dx.doi.org/10.1099/ijs.0.02358-0

31. Hirota K, Aino K, Nodasaka Y, Yumoto I. Oceanobacillus indicireducens sp. nov., a facultative alkaliphile that reduces an indigo dye. Int J Syst Evol Microbiol 2013; 63:1437-1442. PubMed http://dx.doi.org/10.1099/ijs.0.034579-0

32. Yumoto I, Hirota K, Nodasaka Y, Nakajima K. Oceanobacillus oncorhynchi sp. nov., a halotolerant obligate alkaliphile isolated from the skin of a rainbow trout (Oncorhynchus mykiss), and emended description of the genus Oceanobacillus. Int J Syst Evol Microbiol 2005; 55:1521-1524. PubMed http://dx.doi.org/10.1099/ijs.0.63483-0

33. Lee JS, Lim JM, Lee KC, Lee JC, Park YH, Kim CJ. Virgibacillus koreensis sp. nov., a novel bacte- rium from a salt field, and transfer of Virgibacillus picturae to the genus Oceanobacillus as Oceanobacillus picturae comb. nov. with emended descriptions. Int J Syst Evol Microbiol 2006; 56:251-257. PubMed http://dx.doi.org/10.1099/ijs.0.63734-0

34. Ashburner M, Ball CA, Blake JA, Botstein D, Butler H, Cherry JM, Davis AP, Dolinski K, Dwight SS, Eppig JT, et al. Gene ontology: tool for the unification of biology. The Gene Ontology Consortium. Nat Genet 2000; 25:25-29. PubMed http://dx.doi.org/10.1038/75556

35. Weisburg WG, Barns SM, Pelletier DA, Lane DJ. $16 \mathrm{~S}$ ribosomal DNA amplification for phylog enetic study. J Bacteriol 1991; 173:697-703. PubMed

36. Thompson JD, Gibson TJ, Plewniak F, Jeanmoug in F, Higgins DG. The CLUSTAL_X windows interface: flexible strategies for multiple sequence alig nment aided by quality analysis tools. Nucleic Acids Res 1997; 25:4876-4882. PubMed http://dx.doi.org/10.1093/nar/25.24.4876

37. Tamura K, Peterson D, Peterson N, Stecher G, Nei M, Kumar S. MEGA5: Molecular Evolutionary Genetics Analysis using Maximum Likelihood, Evolutionary Distance, and Maximum Parsimony Methods. Mol Biol Evol 2011; 28:2731-2739.

PubMed http://dx.doi.org/10.1093/molbev/msr121

38. Cashion P, Hodler-Franklin MA, McCully J, Franklin M. A rapid method for base ratio determination of bacterial DNA. Anal Biochem 1977; 81:461-466. PubMed http://dx.doi.org/10.1016/0003-2697(77)90720-5

39. De Ley J, Cattoir H, Reynaerts A. The quantitative measurement of DNA hybridization from renaturation rates. Eur J Biochem 1970; 12:133142. PubMed http://dx.doi.org/10.1111/j.14321033.1970.tb00830.x

40. Huss VAR, Festi H, Schleifer KH. Studies on the spectrophotometric determination of DNA hybridization from the renaturation rates. Syst Appl Microbiol 1983; 4:184-192. PubMed http://dx.doi.org/10.1016/S072 3-2020(83)80048$\underline{4}$

41. Wayne LG, Brenner DJ, Colwell RR, Grimont PAD, Kandler O, Krichevsky MI, Moore LH, Moore WEC, Murray RGE, Stackebrandt E, et al. Report of the ad hoc committee on reconciliation of approaches to bacterial systematics. Int J Syst Bacteriol 1987; 37:463-464. http://dx.doi.org/10.1099/00207713-37-4-463 
42. Tindall BJ. A comparative study of the lipid composition of Halobacterium saccharovorum from various sources. Syst Appl Microbiol 1990;

13:12 8-130. http://dx.doi.org/10.1016/S072 32020(11)80158-X

43. Tindall BJ. Lipid composition of Halobacterium lacusprofundi. FEMS Microbiol Lett 1990; 66:199202. http://dx.doi.org/10.1111/j.15746968.1990.tb03996.x

44. Mesbah M, Premachandran U, Whitman W. Precise measurement of the $\mathrm{G}+\mathrm{C}$ content of deoxyribonucleic acid by high performance liquid chromatog raphy. Int J Syst Bact 1989; 39:159-167. http://dx.doi.org/10.1099/00207713-39-2-159

45. Bligh EG, Dyer WJ. A rapid method of total lipid extraction and purification. Can J Biochem Physio/ 1959; 37:911-917. PubMed http://dx.doi.org/10.1139/059-099

46. Tindall BJ, Sikorski J, Smibert RM, Kreig NR. Phenotypic characterization and the principles of comparative systematics. In: Reddy CA, Beveridge TJ, Breznak JA, Marzluf G, Schmidt TM, Snyder LR (eds), Methods for General and Molecular Microbiology, $3^{\text {rd }}$ edition, ASM Press, Washing ton, 2007, p. 330-393.

47. Rhuland LE, Work E, Denman RF, Hoare DS. The behaviour of the isomers of a,e-diaminopimelic acid on paper chromatog rams. I Am Chem Soc 1955; 77:4844-4846. http://dx.doi.org/10.1021/ja01623a047

48. http://www.dsmz.de/microorganisms/main.php?content $\underline{\mathrm{id}=35}$

49. http://ifr48.timone.univmrs.fr/portail2/index.php?option=com content\&ta

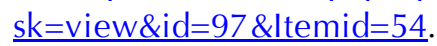

50. Prodigal http://prodigal.ornl.gov/
51. GenBank database.

http://www.ncbi.nlm.nih.gov/genbank

52. Tatusov RL, Galperin MY, Natale DA, Koonin EV. The COG database: a tool for genome-scale analysis of protein functions and evolution. Nucleic Acids Res 2000; 28:33-36. PubMed http://dx.doi.org/10.1093/nar/28.1.33

53. Lowe TM, Eddy SR. tRNAscan-SE: a prog ram for improved detection of transfer RNA genes in genomic sequence. Nucleic Acids Res 1997; 25:955-964. PubMed

54. Lagesen K, Hallin P, Rodland EA, Staerfeldt HH, Rognes T, Ussery DW. RNAmmer: consistent and rapid annotation of ribosomal RNA genes. Nucleic Acids Res 2007; 35:3100-3108. PubMed http://dx.doi.org/10.1093/nar/g km160

55. Krogh A, Larsson B, von Heijni G, Sonnhammer EL. Predicting transmembrane protein topology with a hidden Markov model: application to complete genomes. J Mol Biol 2001; 305:567580. PubMed http://dx.doi.org/10.1006/jmbi.2000.4315

56. Bendtsen JD, Nielsen H, von Heijne G, Brunak S. Improved prediction of sig nal peptides: SignalP 3. 0. J Mol Biol 2004; 340:783-795. PubMed http://dx.doi.org/10.1016/j.jmb.2004.05.028

57. Aziz RK, Bartels D, Best AA, DeJong h M, Disz T, Edwards RA, Formsma K, Gerdes S, Glass EM, Kubal M, et al. The RAST Server: Rapid Annotations using Subsystems Technology. BMC Genomics 2008; 9:75-89. PubMed http://dx.doi.org/10.1186/1471-2164-9-75

58. http://crispr.u-psud.fr/Server

59. Bose $M$, Barber RD. Prophage Finder: a prophage loci prediction tool for prokaryotic genome sequences. In Silico Biol 2006; 6:223-227. PubMed 